\title{
Development of Models for Predicting Some Surface Responses in Oblique Metal Cutting Using Mild Steel and Coated Carbide
}

\author{
I. T. Okafor, J. O. Osarenmwinda and M. K. Onifade
}

\begin{abstract}
Oblique metal cutting is a milling process which constitutes the work piece, tool piece, machine centre and the machinist or operator. This research has been able to obtain some responses such as tool life, and the surface roughness. Most machine elements fail due to some poor surface finish errors such as craters, waviness, flay and lay. Previous researchers have focused more on the absolute value of the surface roughness (Ra) and this cannot provide for all the errors encountered on surface texture. The primary aim of this research is to develop models that can predict the surface roughness of machine parts produced in oblique metal cutting above the absolute value of the average surface roughness and in turn provide a document or framework for machinist which can serve as a guide for machinist. The work has been able to determine a near perfect surface roughness for mild steel using coated carbide as tool piece as the models developed has minimized the effect of surface roughness at run 6,6 and 8 for $\mathrm{Ra}, \mathrm{Rz}$ and maximized TL in the values of 1.071408 micrometer, $\mathbf{2 . 6 6 8 2 9 3}$ micrometer and $\mathbf{4 9 8 3 7 2 3 8}$ seconds respectively. Also. the analysis of variance performed has also shown that is proper to accept the analysis using a significance $\alpha$ level of 0.05 .
\end{abstract}

Index Terms - Oblique, Surface Responses, Milling process, Box-Behnken.

\section{INTRODUCTION}

The oblique metal cutting process is a chip removal process from blanks, never at $90^{\circ}$ (degrees). Our focus is metal removal process in milling machine, taking into cognizance the surface roughness. Practically, most operations in modern manufacturing involve the oblique cutting process. Most researchers have considered the economic effects of optimizing the oblique process rather than the technological drawbacks in oblique metal cutting. The surface prediction responses intended to achieve from this research will form a framework or document for machinist and serve as a guide. [1] examined the influence of cutting parameters in face milling semi-solid AA 7075 using the carbide tool in other to obtain the surface roughness and tool wear. [2] investigated the effect of heat developed during machine on surface roughness and he posited that an increase in heat developed leads to increase in coarseness of surface roughness. The paucity of information of determining surface roughness above the absolute average (Ra) has hindered the development of the machine tool industry especially in developing countries, this research will proctor responses from oblique metal cutting processes in oblique

Submitted on February 26, 2021.

Published on March 19, 2021.

I. T. Okafor, Marine Engineering School, Nigerian Naval Engineering College, Sapele Delta State, Nigeria.

(e-mail: izunnaokafor@gmail.com) metal cutting procedures, also no economy can industrial in the manufacturing industry, as this research tries to fill that gap in areas of the surface roughness above the absolute average (Ra) to the extent of determining $\mathrm{Rz}$, and TL while obtaining the machine time and tool life with relations to the tool life equation (3).

\section{LITERATURE}

[3] devised a procedure for predicting surface roughness in-process. In their research, roughness of machined surface was assumed to be generated by the relative motion between tool and work piece and the geometric factors of a tool. The relative motion caused by the machining process could be measured in process using a cylindrical capacitive displacement sensor (CCDS). The CCDS was installed at the quill of a spindle and the sensing was not disturbed by the cutting established a procedure for predicting. [5] proposed the genetic programming approach to predict surface roughness based on cutting parameters (spindle speed, feed rate and depth of cute) and on vibrations between cutting tool and work piece. From this research, they were able to conclude that the models that involve the three cutting parameters and vibrating, generates the most concise predictions of surface roughness by using genetic programming. [6] used ANN method to predict surface roughness in turning process. This method was found to be very well effective, and it makes use of fewer training and testing data. [7] developed a model for surface roughness in end milling by using Swarm Intelligence. From their studies, data was collected from CNC cutting experiments using Design of Experiments approach. [8] studied the effect of cutting parameters on surface roughness in turning of titanium alloys using RSM. Their results reveal that the feed rate was the most influential factor which affects the surface roughness. The order of importance was feed rate, followed by depth of cut and cutting speed. [9] studied the effect of feed rate, tool nose radius, cutting speed and depth of cut on the surface roughness of AISI 410 steel using RSM in turning. Their results reveal that surface roughness increases with the increase in the feed rate and decreases with the increase in the nose radius. Similarly, [10] studied the effects of the flow-forming parameters such as speed of the mandrel, longitudinal feed, and amount of coolant used on the surface

J. O. Osarenmwinda, University of Benin, Benin City, Edo State, Nigeria. M. K. Onifade, Bells University of Technology, Ota, Ogun State Nigeria. 
roughness of flow-formed AA 6061 alloy tube using RSM. [11] used BBD to determine the influence of machining parameters on the performance of electro discharge machining (EDM) of Ti6Al4V with a bundled electrode. [12] applied BBD to the optimization of process parameters in foam cup molding. [13] carried out machining in HMT FN1U semi-automatic milling machine. The milling machine is equipped with $2.2 \mathrm{~kW}$ spindle motor and $0.75 \mathrm{~kW}$ feed motor. End milling operations were performed with a $20 \mathrm{~mm}$ diameter end mill cutter (TE90AX 220-09-L). TiCN coated tungsten carbide inserts (AXMT 090308 PER-EML TT8020) were used in the experiment. [14], they have used factorial designs for their experimental study of investigating the surface roughness in aluminum 7075-T6 face milling process by $\mathrm{CNC}$ milling machine and the result showed that the factors effecting the surface roughness were the feed ratio and the speed while the depth did not affect the surface roughness. This research work has tried to obtain six responses form the experiment performed thereby to predict a more robust surface roughness of the machined part also the six responses were investigated thoroughly in other to bring a better understanding of the subject matter.

\section{Methodology}

The previous information available in the literature work reviewed served as a guide to the selection of the key engineering steps that are involved in oblique metal cutting processes. A Box-Behnken response surface design will be created using widely established machining parameters, namely cutting speed, feed rate and depth of cut. The responses from the designed experiment were the surface roughness in four variables, namely, Arithmetic Average of
Absolute Values (Ra), Average Distance between Highest Peak and Lowest Valley (Rz), and as well as the empirical tool life for the various experimental runs.

\section{A. Description of Machine Tools and Process Parameters}

The metal cutting process parameters and their levels at three different values were selected based on the optimum process parameters selection chart developed by [20]. Furthermore, the literature of information on process parameters provided by [16]-[18], as well as [19] will provide a guide in selecting of values. The corresponding spindle speeds in rev/min for the cutting speeds were obtained using the expression in (1) [15]:

$$
N=\frac{1000 s}{\pi D}
$$

where $N$ is the spindle speed, $s$ is the cutting speed; $D$ is the work-piece diameter.

The appropriate diameter of the work-piece in millimetre that fitted into the dimension for industrial applications was $80 \mathrm{~mm}$.

\section{B. Description of Surface Roughness Tester and Its Accessories}

The Landtek surface roughness tester is compatible with four standards namely, ISO, DIN, ANSI and JIS. It is a widely used device in production site to measure surface roughness of various machinery (Processed parts), and calculates corresponding parameters according to selected measuring conditions and clearly displays all measurement parameters both on the device and via the RS232 connector cable on the personal computer.

\begin{tabular}{|c|c|c|c|c|c|c|c|}
\hline Runs & Block & $\begin{array}{l}\text { Cutting } \\
\text { Speed }\end{array}$ & $\begin{array}{l}\text { Feed } \\
\text { Rate }\end{array}$ & $\begin{array}{c}\text { Depth of } \\
\text { Cut }\end{array}$ & $\begin{array}{c}\text { Machining } \\
\text { Time }\end{array}$ & $\begin{array}{c}\text { Surface } \\
\text { Roughness }\end{array}$ & $\begin{array}{l}\text { Tool } \\
\text { Life }\end{array}$ \\
\hline 1 & Mild Steel x Carbide & - & - & 0 & & & \\
\hline 2 & Mild Steel x Carbide & + & - & 0 & & & \\
\hline 3 & Mild Steel x Carbide & - & + & 0 & & & \\
\hline 4 & Mild Steel x Carbide & + & + & 0 & & & \\
\hline 5 & Mild Steel x Carbide & - & 0 & - & & & \\
\hline 6 & Mild Steel x Carbide & + & 0 & - & & & \\
\hline 7 & Mild Steel x Carbide & - & 0 & + & & & \\
\hline 8 & Mild Steel x Carbide & + & 0 & + & & & \\
\hline 9 & Mild Steel x Carbide & 0 & - & - & & & \\
\hline 10 & Mild Steel x Carbide & 0 & + & - & & & \\
\hline 11 & Mild Steel x Carbide & 0 & - & + & & & \\
\hline 12 & Mild Steel x Carbide & 0 & + & + & & & \\
\hline 13 & Mild Steel x Carbide & 0 & 0 & 0 & & & \\
\hline 14 & Mild Steel x Carbide & 0 & 0 & 0 & & & \\
\hline 15 & Mild Steel x Carbide & 0 & 0 & 0 & & & \\
\hline
\end{tabular}

\section{Theory of Tool-Life Prediction}

Chen and $\mathrm{Su}$ [19] presented an extended Taylor's equation developed by Armarego and Brown [20] as shown in (8) and (9) for rough and finish machining respectively.

$$
\begin{aligned}
& T=\frac{C_{o}}{V_{r}^{\alpha} f_{r}^{\beta} d_{r}^{\gamma}} \\
& T=\frac{C_{o}}{V_{s}^{\alpha} f_{s}^{\beta} d_{s}^{\gamma}}
\end{aligned}
$$

where $\alpha, \beta, \gamma$ and $C_{o}$ are constants of the Taylor tool-life equation.

\section{Model Developed}

The objective of the experiment was to allow an estimation of interactive and quadratic effects and therefore provide a predictive model that obtained an improved or optimal metal cutting process settings, troubleshoot process problems and weak points, as well as represent the experimental observations as an empirical mathematical function. The nonlinear response surface model developed for the Box- 
Behnken design to minimize surface roughness and maximize tool life and machining time is shown below.

$R_{a}=-2.330049+0.5726996 v+0 f-55.82695(a p)+$ $0 v^{2}+0 f^{2}-1303769(a p)^{2}-0.428037 v f+$ $220.75873 v(a p)+0 f(a p)$

$$
\begin{aligned}
R_{z}=-8.868928 & +1.9272114 v+0 f-698.7007(a p) \\
& +0 v^{2}+0 f^{2}-3237769(a p)^{2} \\
& -1.396363 v f+649.60677 v(a p) \\
& +0 f(a p)
\end{aligned}
$$

$T L=83133356-8570657 v+0 f+3.106000(a p)+$ $0 v^{2}+0 f^{2}-4.28013(a p)^{2}+3473986.4 v f+$

$3.0924009 v(a p)+0 f(a p)$.

\section{PREDictions BASED On RESPONSE SURFACE REGRESSION MODEL}

Quadratic response regression models developed have the characteristics of both polynomial regression and fractional factorial regression designs. The results of the response surface prediction for Ra, in micrometer, when mild steel work-piece was machined using P10 carbide insert tool are shown in Table. III. The predicted values (RaHat) for the experimental response (Ra) have minimum associated residuals as shown in the error column. The square of the errors supported this claim by having majority of the values less than unity.

\begin{tabular}{|c|c|c|c|c|c|c|c|}
\hline \multicolumn{8}{|c|}{ TOOL COMBINATION } \\
\hline Runs & $\mathrm{v}(\mathrm{m} / \mathrm{s})$ & $\mathrm{f}(\mathrm{m} / \mathrm{s})$ & $\mathrm{ap}(\mathrm{m})$ & $\mathrm{Ra}$ & RaHat & Error & SqError \\
\hline 1 & 10.4667 & 0.62800 & 0.0010 & 1.887 & 1.801703 & 0.085297 & 0.00727555 \\
\hline 2 & 18.8333 & 1.13000 & 0.0010 & 1.735 & 2.14448 & -0.40948 & 0.167673469 \\
\hline 3 & 10.4667 & 0.62800 & 0.0010 & 2.42 & 1.801703 & 0.618297 & 0.382290973 \\
\hline 4 & 18.8333 & 1.13000 & 0.0010 & 0.622 & 2.14448 & -1.52248 & 2.317943858 \\
\hline 5 & 10.4667 & 0.62800 & 0.0005 & 0.956 & 1.652139 & -0.69614 & 0.484610025 \\
\hline 6 & 18.8333 & 1.13000 & 0.0005 & 1.693 & 1.071408 & 0.621592 & 0.386376166 \\
\hline 7 & 10.4667 & 0.62800 & 0.0015 & 1.292 & 1.299382 & -0.00738 & 0.0000544644 \\
\hline 8 & 18.8333 & 1.13000 & 0.0015 & 3.876 & 2.565666 & 1.310334 & 1.716974774 \\
\hline 9 & 14.6500 & 0.87900 & 0.0005 & 2.402 & 1.81122 & 0.59078 & 0.349021185 \\
\hline 10 & 14.6500 & 0.87900 & 0.0005 & 1.295 & 1.81122 & -0.51622 & 0.266482934 \\
\hline 11 & 14.6500 & 0.87900 & 0.0015 & 2.268 & 2.38197 & -0.11397 & 0.012989228 \\
\hline 12 & 14.6500 & 0.87900 & 0.0015 & 1.193 & 2.38197 & -1.18897 & 1.413650362 \\
\hline 13 & 14.6500 & 0.87900 & 0.0010 & 3.148 & 2.422537 & 0.725463 & 0.526296096 \\
\hline 14 & 14.6500 & 0.87900 & 0.0010 & 2.251 & 2.422537 & -0.17154 & 0.029425053 \\
\hline 15 & 14.6500 & 0.87900 & 0.0010 & 3.097 & 2.422537 & 0.674463 & 0.454899903 \\
\hline
\end{tabular}

TABLE II: INPUT PROCESS PARAMETERS FOR MILD STEEL WORK-PIECE MACHINED WITH CARBIDE INSERT TOOL

\begin{tabular}{ccccccccc}
\hline \multirow{2}{*}{ Runs } & $\mathrm{L}(\mathrm{mm})$ & \multicolumn{7}{c}{ Process Parameters } \\
\cline { 3 - 9 } & & $\mathrm{v}(\mathrm{mpm})$ & $\mathrm{f}(\mathrm{mm} / \mathrm{rev})$ & $\mathrm{ap}(\mathrm{mm})$ & $\mathrm{v}(\mathrm{m} / \mathrm{s})$ & $\mathrm{f}(\mathrm{mmPM})$ & $\mathrm{f}(\mathrm{m} / \mathrm{s})$ & $\mathrm{ap}(\mathrm{m})$ \\
\hline 1 & 50 & 628 & 1.5 & 1 & 10.4667 & 0.04110 & 0.00247 & 0.0010 \\
2 & 50 & 1130 & 1.5 & 1 & 18.8333 & 0.07396 & 0.00444 \\
3 & 50 & 628 & 4.5 & 1 & 10.4667 & 0.12331 & 0.00740 & 0.0010 \\
4 & 50 & 1130 & 4.5 & 1 & 18.8333 & 0.22188 & 0.01331 & 0.0010 \\
5 & 50 & 628 & 3 & 0.5 & 10.4667 & 0.08221 & 0.00493 & 0.0005 \\
6 & 50 & 1130 & 3 & 0.5 & 18.8333 & 0.14792 & 0.00888 & 0.0005 \\
7 & 50 & 628 & 3 & 1.5 & 10.4667 & 0.08221 & 0.00493 & 0.0015 \\
8 & 50 & 1130 & 3 & 1.5 & 18.8333 & 0.14792 & 0.00888 & 0.0015 \\
9 & 50 & 879 & 1.5 & 0.5 & 14.6500 & 0.05753 & 0.00345 & 0.0005 \\
10 & 50 & 879 & 4.5 & 0.5 & 14.6500 & 0.17259 & 0.01036 & 0.0005 \\
11 & 50 & 879 & 1.5 & 1.5 & 14.6500 & 0.05753 & 0.00345 & 0.0015 \\
12 & 50 & 879 & 4.5 & 1.5 & 14.6500 & 0.17259 & 0.01036 & 0.0015 \\
13 & 50 & 879 & 3 & 1 & 14.6500 & 0.11506 & 0.00690 & 0.0010 \\
14 & 50 & 879 & 3 & 1 & 14.6500 & 0.11506 & 0.00690 & 0.0010 \\
15 & 50 & 879 & 3 & 1 & 14.6500 & 0.11506 & 0.00690 & 0.0010 \\
\hline
\end{tabular}

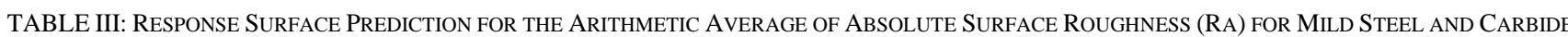

The plot of the experimental observations and the predicted values based on the developed response surface model for Ra, for mild steel and carbide tool combination, is shown in Fig. 1.

The results of the response surface prediction for $\mathrm{Rz}$, in microns, when mild steel work-piece was machined using P10 carbide insert tool are shown in Table. IV The predicted values (RzHat) for the experimental response (Rz) have sizable associated residuals, as shown in the error column, for runs $4,8,6,13,3,15,12,5,10$ and 2 . The square of the errors for these runs supported this claim by having values greater than unity.

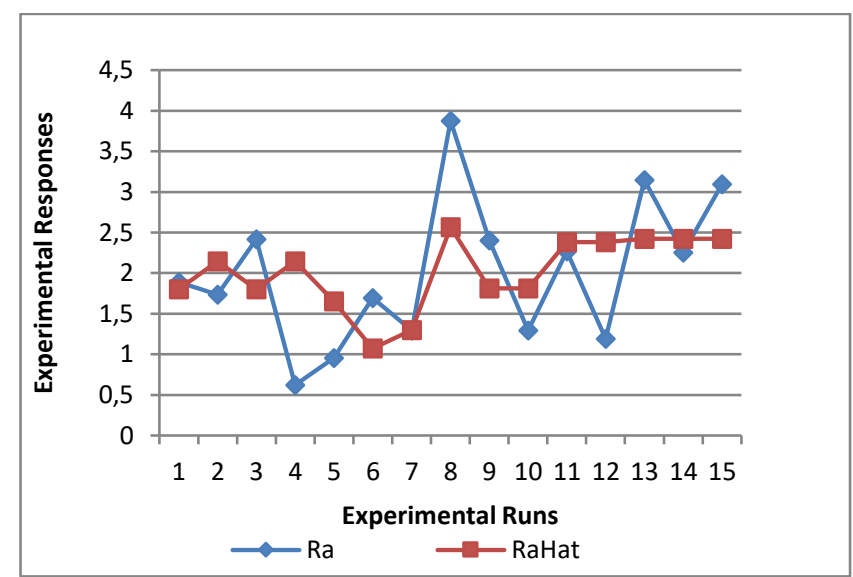

Fig. 1. Plot of Ra and RaHat for Mild Steel and Carbide Tool Combination. 
TABLE IV: Response Surface PRediction for the Average Distance betweEn Highest PeAK and Lowest Valley SuRfaCe RoughnesS

\begin{tabular}{cccccccc}
\multicolumn{7}{c}{$(\mathrm{Rz})$ FOR MILD STEEL AND CARBIDE TOOL COMBINATION } \\
\hline Runs & $\mathrm{v}(\mathrm{m} / \mathrm{s})$ & $\mathrm{f}(\mathrm{m} / \mathrm{s})$ & $\mathrm{ap}(\mathrm{m})$ & $\mathrm{Rz}$ & $\mathrm{RzHat}$ & Error & SqError \\
\hline 1 & 10.4667 & 0.62800 & 0.0010 & 5.337 & 4.986912 & 0.350088 & 0.122561568 \\
2 & 18.8333 & 1.13000 & 0.0010 & 4.906 & 6.007746 & -1.10175 & 1.21384408 \\
3 & 10.4667 & 0.62800 & 0.0010 & 6.846 & 4.986912 & 1.859088 & 3.456207983 \\
4 & 18.8333 & 1.13000 & 0.0010 & 1.759 & 6.007746 & -4.24875 & 18.05184192 \\
5 & 10.4667 & 0.62800 & 0.0005 & 2.704 & 4.36498 & -1.66098 & 2.758855866 \\
6 & 18.8333 & 1.13000 & 0.0005 & 4.787 & 2.668293 & 2.118707 & 4.488921022 \\
7 & 10.4667 & 0.62800 & 0.0015 & 3.442 & 3.989959 & -0.54796 & 0.300259306 \\
8 & 18.8333 & 1.13000 & 0.0015 & 10.96 & 7.728315 & 3.231685 & 10.44378961 \\
9 & 14.6500 & 0.87900 & 0.0005 & 5.846 & 4.982841 & 0.863159 & 0.745043594 \\
10 & 14.6500 & 0.87900 & 0.0005 & 3.662 & 4.982841 & -1.32084 & 1.744620742 \\
11 & 14.6500 & 0.87900 & 0.0015 & 6.415 & 7.325341 & -0.91034 & 0.828721469 \\
12 & 14.6500 & 0.87900 & 0.0015 & 5.552 & 7.325341 & -1.77334 & 3.144739731 \\
13 & 14.6500 & 0.87900 & 0.0010 & 8.905 & 6.963533 & 1.941467 & 3.769292511 \\
14 & 14.6500 & 0.87900 & 0.0010 & 6.367 & 6.963533 & -0.59653 & 0.355852112 \\
15 & 14.6500 & 0.87900 & 0.0010 & 8.76 & 6.963533 & 1.796467 & 3.2272922 \\
\hline
\end{tabular}

TABLE V: RESPONSE SURFACE PREDICTION FOR THE TOOL LIFE (TL) FOR MILD STEEL AND CARBIDE TOOL COMBINATION

\begin{tabular}{|c|c|c|c|c|c|c|c|}
\hline Runs & $\mathrm{v}(\mathrm{m} / \mathrm{s})$ & $\mathrm{f}(\mathrm{m} / \mathrm{s})$ & $\mathrm{ap}(\mathrm{m})$ & TL $(\mathrm{sec})$ & TLHat & Error & SqError \\
\hline 3 & 10.4667 & 0.62800 & 0.0010 & 20281644 & 16261890 & 4019754 & $1.61584 \mathrm{E}+13$ \\
\hline 5 & 10.4667 & 0.62800 & 0.0005 & 36494042 & 16261890 & 20232151 & $4.0934 \mathrm{E}+14$ \\
\hline 6 & 18.8333 & 1.13000 & 0.0005 & 13521096 & -4348464 & 17869560 & $3.19321 \mathrm{E}+14$ \\
\hline 7 & 10.4667 & 0.62800 & 0.0015 & 17382069 & 16261890 & 1120179 & $1.2548 \mathrm{E}+12$ \\
\hline 10 & 14.6500 & 0.87900 & 0.0005 & 24329361 & 2308970 & 22020391 & $4.84898 \mathrm{E}+14$ \\
\hline 11 & 14.6500 & 0.87900 & 0.0015 & 26073104 & 2308970 & 23764134 & $5.64734 \mathrm{E}+14$ \\
\hline 12 & 14.6500 & 0.87900 & 0.0015 & 26073104 & 2308970 & 23764134 & $5.64734 \mathrm{E}+14$ \\
\hline 13 & 14.6500 & 0.87900 & 0.0010 & 36494042 & 2308970 & 34185072 & $1.16862 \mathrm{E}+15$ \\
\hline 14 & 14.6500 & 0.87900 & 0.0010 & 26073104 & 2308970 & 23764134 & $5.64734 \mathrm{E}+14$ \\
\hline 15 & 14.6500 & 0.87900 & 0.0010 & 17382069 & 2308970 & 15073099 & $2.27198 \mathrm{E}+14$ \\
\hline
\end{tabular}

The plot of the experimental observations and the predicted values based on the developed response surface model for Rz, for mild steel and carbide tool combination, is shown in Fig. 2.

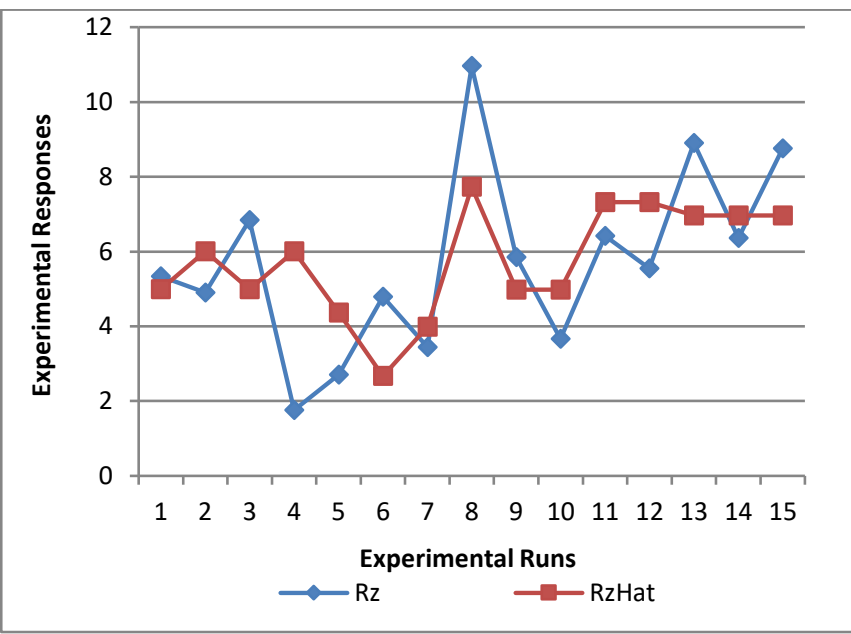

Fig. 2. Plot of Rz and RaHat for Mild Steel and Carbide Tool Combination.

The results of the response surface prediction for TL, in seconds, when mild steel work-piece was machined using P10 carbide insert tool are shown in Table V. The predicted values (TLHat) for the experimental response (TL) have sizable associated residuals, as shown in the error column. The square of the errors supported this claim by having values greater than unity.

The plot of the empirical and the predicted values based on the developed response surface model for Tool-Life, for mild steel and carbide tool combination, is shown in Fig. 3.

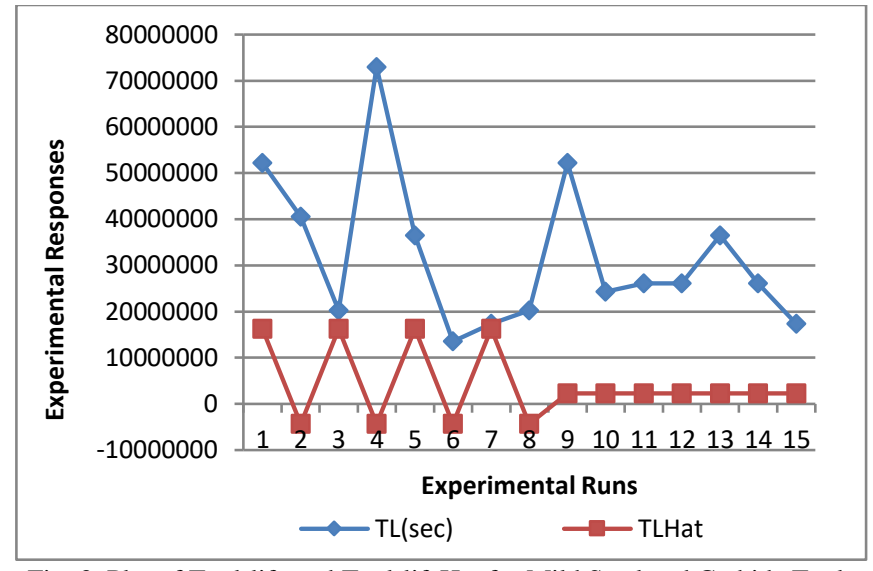

Fig. 3. Plot of Tool-life and Tool-lifeHat for Mild Steel and Carbide Tool Combination.

The plot shows that the tool-life declines from runs 1 to 8 in a sinusoidal pattern. When the tool was utilized based on the combinations of process parameter levels indicated at runs 11, 12 and 14, the tool-life remained same seconds respectively.

TABLE VI: SUMMARY OF LACK-OF-FIT FOR MILD STEEL AND CARBIDE TOOL COMBINATION USING (ANOVA)

\begin{tabular}{|c|c|c|c|c|}
\hline Responses & Models & Source & p-value & Decision \\
\hline $\mathrm{Ra}$ & RaHat & $\begin{array}{l}\text { Lack-of- } \\
\text { fit }\end{array}$ & 0.0766 & $\begin{array}{c}\text { Evidence } \\
\text { not enough }\end{array}$ \\
\hline $\mathrm{Rz}$ & RzHat & $\begin{array}{l}\text { Lack-of- } \\
\text { fit }\end{array}$ & 0.0961 & $\begin{array}{l}\text { Evidence } \\
\text { not enough }\end{array}$ \\
\hline TL & TLHat & $\begin{array}{c}\text { Lack-of- } \\
\text { fit }\end{array}$ & 0.2755 & $\begin{array}{l}\text { Evidence } \\
\text { not Enough }\end{array}$ \\
\hline
\end{tabular}




\section{CONCLUSION}

From the investigation carried out, the researcher was able to develop a theoretical data to represent machinability ratings that will be helpful for an effective machine tool industry in terms of surface texture determination, regarding arithmetic average of absolute values ( $\mathrm{Ra}$ ), average distance between the highest peak and lowest valley in each of the length (Rz) and the Tool Life (TL) of the cutting tool. The statistics performed with analysis of variance (ANOVA) to obtain the lack of fit taking a significant $\alpha$ level of 0.05 , has shown that there is not enough evidence to reject the null hypothesis therefore the alternative hypothesis is rejected. To boot the relation above has shown that the models developed has minimized the effect of surface roughness at run 6,6 and 8 for $\mathrm{Ra}, \mathrm{Rz}$ and maximized TL in the values of 1.071408 micrometer, 2.668293 and 49837238 seconds.

\section{REFERENCES}

[1] Surasit, R., Jaknarin, C., Worapong, B., and Romadorn, B., (2014) Influence of cutting parameters in face milling semi-solid AA 7075 Using Carbide tool affected the surface roughness and tool wear; Energy Procedia 56: 448-457.

[2] Fang, X. D. and Safi-Jahanshaki (1997). A New Algorithm for Developing a Reference Model for Producing Surface Roughness in finish Machining of Steels. International Journal of Production Research, Vol 35 (1), 179-197.

[3] Cheng, C. and Li, C. (1993) Constructing Orthogonal Fractional Factorial Designs when some Factor-Level Combinations are Debarred, Technometrics, Vol. 35, No 3, PP. 277-280.

[4] Oktem, H., Erzurumlu, T. and Kurtaran, H. (2005) Application of Response Surface Methodology in the Optimization of Cutting Conditions for Surface Roughness, Journal of Material Processing Technology, Vol. 170, PP. $11-16$.

[5] Tansel, I. N., Ozcelik, B., Bao, W.Y., Chen, P., Rincon, D., Yang, S Y. and Yenilmez, A. (2006) Selection of Optimal Cutting Conditions by using GONNS, International Journal of Machine Tools and Manufacture, Vol. 46, pp. 26-35.

[6] Hashmi, K.H., Zakria, G., Raza, M.B. and Khahl, S. (2015) Optimization of Process Parameters for High Speed Machining of Ti6A1-4V Using Response Surface Methodology, The International Journal of Advanced Manufacturing Technology, Vol. 85, Issue 5, PP. 1847-1856.

[7] Raja, S. B. and Baskar, N. (2012) Application of Particle Swarm Optimisation Technique for Achieving Desired Milled Surface Roughness in Minimum Machining Time. International Journal of Expert Systems with Applications, Vol. 39, pp. 5982-5989.

[8] Makadia, A.J. and Nanavati, J.I., (2013), Optimization of machining parameters for turning operations based response surface methodology. Elsiever Journal of Measurement. Vol.46. pp. 15211529.

[9] Dhavamani, C. and Alwarsamy, T. (2011) Review on Optimisation of Machining Operation, International Journal of Academic Research, Vol. 3, No. 3, pp. 476-485.

[10] Grzesik, W. (2008) Influence of Tool Wear on Surface Roughness in Hard Turning using different Shaped Ceramic Tools, Technical Paper, Department of manufacturing Engineering and Production Automation, Opole University of Technology, Opole, Poland, Vol. 265, PP. 327-335.

[11] Watmon, T.B., Xiao D. and Okello - Obeli, P. (2016) Finite Element Analysis of Orthogonal Metal Machining, Internatinal Journal of Scientific Research and Innovative Technology, Vol. 3, No. 2, PP. 4655.

[12] Pillai, P. M. and Srinivasan, J. (1987) Age Productivity of Machine Tools in India, Economic and Political Weekly, Vol. 22, No. 35, PP. M95 - M97 + M99 - M100.

[13] Ozel, T. and Karpat, Y. (2005) Predictive Modelling of Surface Roughness and Tool Wear in Hard Turning using Regression and Neural Networks. Journal of Machine Tools and Manufacture, Vol. 45, pp. 467-479.

[14] Jain, R. K. (2009) Production Technology, Khanna Publishers, New Delhi, pp. 476.
[15] Born, D.K. and Goodman, W.A (2001) An Empirical Survey on the Influence of Machining Parameters on Tool Wear in Diamond Turning of Large Single-Crystal Silicon Optics, Journal of the International Societies for Precision Engineering and Nanotechnology, Vol. 25, PP. 247-256.

[16] Igboanugo, A. C. and Onifade, M. K. (2012) Kronecker Product Analytical Approach to ANOVA of Surface Roughness Optimization. Journal of the Nigerian Association of Mathematical Physics, Vol. 20, pp. 399-412.

[17] Igboanugo, A. C. and Ovuworie, G. C. (2007) Surface Roughness in Turning Operation: Tool Geometry, Depth of Cut and Feed Rate Intercorrelations. Nigeria Journal of Engineering Research and Development, Vol. 6, No. 1 pp. 1-9.

[18] Cheng, C. and Li, C. (1993) Constructing Orthogonal Fractional Factorial Designs when some Factor-Level Combinations are Debarred, Technometrics, Vol. 35, No 3, PP. 277-280.

[19] Chen, M. -C. and Su, C.-T. (1998) Optimisation of Machining Conditions for Turning Cylindrical Stocks into Continuous Finished Profiles, International Journal of Production Research, Vol. 36, No 8, pp. 2115-2130.

[20] Armarego, E. J. A. and Brown, R. H. (1969) The Machining of Metal, Englewood Cliffs, NJ: Prentice Hall. 